\title{
PLANKTON STRUCTURE OF THE SHALLOW COASTAL ZONE AT ADMIRALTY BAY, KING GEORGE ISLAND, WEST ANTARCTIC PENINSULA (WAP): CHLOROPHYLL BIOMASS AND SIZE-FRACTIONATED CHLOROPHYLL DURING AUSTRAL SUMMER 2010/2011
}

http://dx.doi.org/10.4322/apa.2014.105

Márcio Murilo Barboza Tenório*, José Juan Barrera-Alba** \& Denise Rivera Tenenbaum***

Laboratório de Fitoplâncton Marinho, Instituto de Biologia, Universidade Federal do Rio de Janeiro - UFRJ, Av. Brigadeiro Trompowsky, s/n, CCS, BL A, SL.67, Cidade Univers., CEP 20530-310, Rio de Janeiro, RJ, Brazil e-mails: *marcio.tenorio@biologia.ufr.br, **juanalba@biologia.ufri.br, ***deniser@biologia.ufri.br

\begin{abstract}
Chlorophyll a concentration and size structure of the phytoplankton community were studied in Admiralty Bay in early and late summer of 2010/2011, using spectrofluorometry chlorophyll analysis. The contribution of three size fractions: picoplankton $(<2 \mu \mathrm{m})$, ultraplankton $(2-10 \mu \mathrm{m})$ and microplankton $(>10 \mu \mathrm{m})$ in chlorophyll a biomass was analysed. Chlorophyll a biomass increased from early to late summer and showed a relatively spatial homogeneity. During early summer biomass was co-dominated by ultra and microplankton size classes in with account 84\% of Chla biomass, while in the late summer $>10 \mu \mathrm{m}$ size classes dominated completely Chla concentrations (88\%).
\end{abstract}

Keywords: Size Structure, Spectrofluorometry, Antarctic, King George Island

\section{Introduction}

Phytoplankton pigments (chlorophylls, carotenoids, phycobiliproteins) remain a major source of information on biomass, community structure, dynamic, and physiological state of phytoplankton (Neveux et al., 2009). Among the pigments, chlorophyll $a$ concentration is used to access biomass of phytoplankton. In Antarctic waters, chlorophyll $a$ and rates of primary production are generally low, yet concentrations of inorganic nutrients are very high (Mitchell \& Holm-Hansen, 1991). Chlorophyll $a$ distribution in the Southern Ocean also showed high spatial and temporal variability (Marrari et al., 2008).

Although chlorophyll biomass is important, it does not necessarily draw out the relationships between primary producers and other organisms higher up the food chain (Gin et al., 2000). This inconvenient can be largely elucidated by assessing the size structure of the plankton community. The size distribution of the primary producers plays an important role in the trophic organization of marine ecosystems and in the global flux of organic matter towards the aphotic layer (Jacques \& Panouse, 1991). Size structures of phytoplankton communities are quantitative expressions of the relative success of certain different community size compartments to survive or grow in an essentially unstable environment controlled by physical and chemical characteristics (Rodriguez \& Guerrero, 1994). Recent studies demonstrated that in the West Antarctic Peninsula (WAP), picoplankton and nanoplankton are the dominant groups, with microplankton diatoms being the second group in abundance (Montes-Hugo et al., 2009). In this study we present the preliminary results of the monitoring program of chlorophyll $a$ biomass and chlorophyll $a$ size fraction biomass conducted in Admiralty Bay, King George Island, during the summer of 2010/2011. 


\section{Materials and methods}

\section{Study area}

Admiralty Bay $\left(62^{\circ} 03^{\prime}-12^{\prime} \mathrm{S}, 58^{\circ} 18^{\prime}-38^{\prime} \mathrm{W}\right)$, located at King George Island, is a deep ford-like embayment with 500 m maximum depth at its centre (Rakusa-Suszczewski et al., 1993). The waters from the bay mix with the deep oceanic waters from the Bellingshausen and Weddell Seas at its southern opening, which connects to the Bransfield Strait (Lipski, 1987). The maximum depth varies between $60 \mathrm{~m}$ close to the shore and $500 \mathrm{~m}$ in the centre of the bay. Deep currents generated by tides, frequent upwellings, vertical mixing and current velocities of $30-100 \mathrm{~cm} \mathrm{~s}^{-1}$ in the $0-100$ $\mathrm{m}$ surface stratum are characteristic of the bay (RakusaSuszczewski, 1993).

\section{Sampling}

The fractionate analysis of chlorophyll $a$ was performed from splits of the $5 \mathrm{~L}$ water sample collected using a Niskin bottle from the surface, middle water column and near the bottom $(\approx 30 \mathrm{~m})$ at five stations in six surveys (December 2010 to March 2011). Temperature was measured in situ while salinity analyses were carried out by the Laboratório de Química Orgânica (IO-USP).

\section{Chlorophyll a}

Water samples (0.3L) were filtered onto Whatman ${ }^{\circledR} \mathrm{GF} / \mathrm{F}$ (Ø $47 \mathrm{~mm}$ ) for total pigment analyses, while 0.5-1L were used for the size structure study. In the latter case at CF, MP and AR stations, water sampled at 3 depths was fractionated by serial filtration on $10 \mu \mathrm{m}$ and $2 \mu \mathrm{m}$ polycarbonate filters and $\mathrm{GF} / \mathrm{F}$ ( $\varnothing 47 \mathrm{~mm}$ ) to access the pigment concentration of picoplankton $(<2 \mu \mathrm{m})$, ultra plankton $(2-10 \mu \mathrm{m})$ and microplankton $(>10 \mu \mathrm{m})$. The filters were folded, placed into a $1.2 \mathrm{~mL}$ cryotube and immediately quick-frozen in liquid nitrogen $\left(-196^{\circ} \mathrm{C}\right)$ and stored at $-80^{\circ} \mathrm{C}$. For pigment extraction, GF/F filters were dipped in $5.4 \mathrm{~mL}$ of $100 \%$

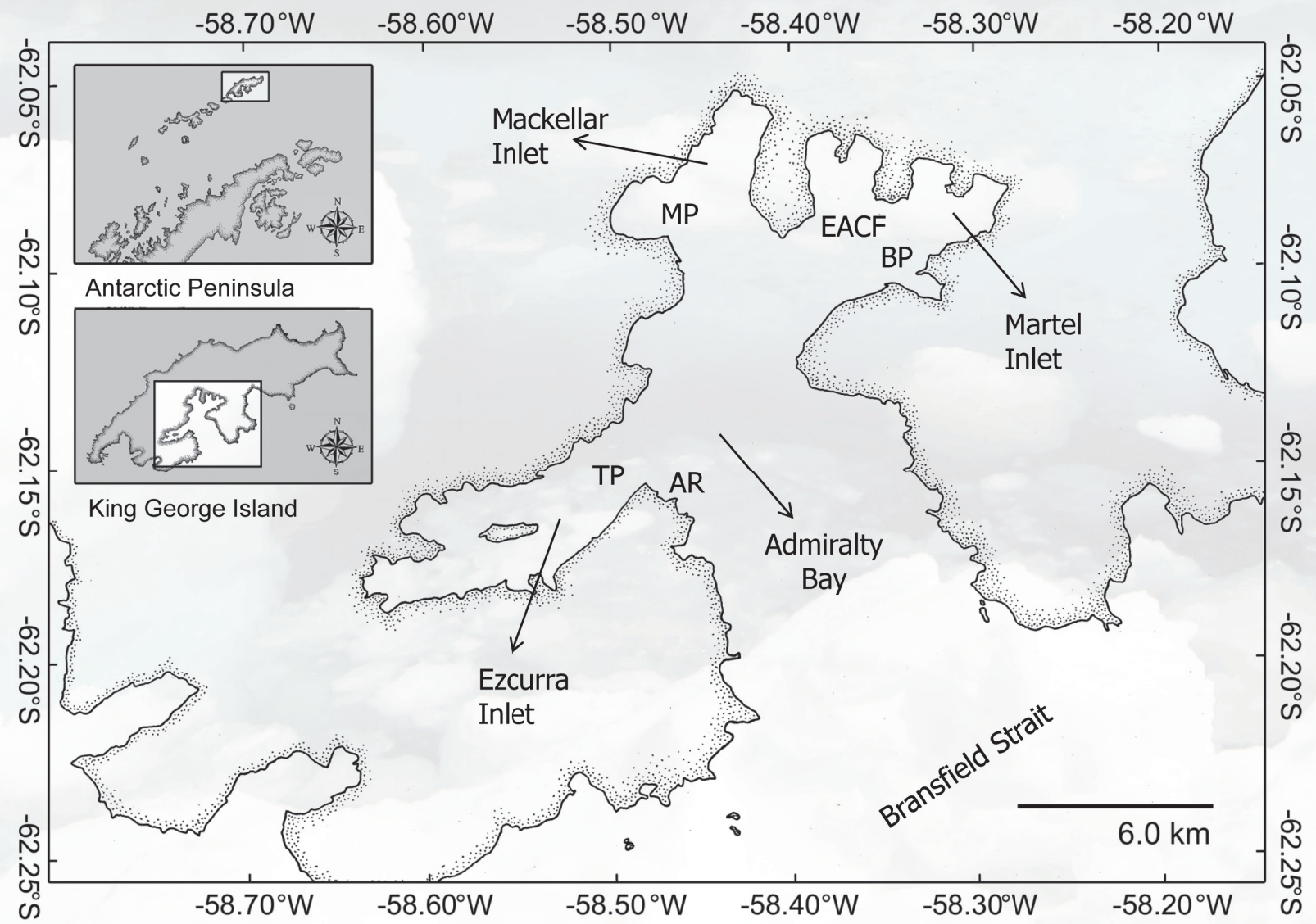

Figure 1. Study area with the position of the sampling sites: Ferraz Station (CF), Botany Point (BP), Machu Picchu (MP), Thomas Point (TP), Arctowski (AR), modified from Moura (2009). 
acetone (final concentration $\approx 90 \%$ acetone taking into account water retention by the filter $(\approx 0.621 \pm 0.034 \mathrm{~mL})$ and ground with the freshly broken end of a glass rod, and left in the dark at $4{ }^{\circ} \mathrm{C}$ for a $12 \mathrm{~h}$ extraction. Polycarbonate filters, on the other hand, were just left in the dark at $4{ }^{\circ} \mathrm{C}$ for a $24 \mathrm{~h}$ in $5 \mathrm{~mL}$ of $90 \%$ acetone. Following extraction, the tubes were centrifuged for $5 \mathrm{~min}$ at $3500 \mathrm{rpm}$ and the extracted fluorescence was measured with a Varian Cary Eclipse $^{\circledast}$ spectrofluorometer. Concentrations of chlorophyll $a$ were assessed using a modified version of Neveux \& Lantoine’s (1993) method in Tenório et al. (2011).

\section{Statistical analyses}

Differences among surveys $(n=6)$, sampling stations $(\mathrm{n}=5)$, vertical profile $(\mathrm{n}=3)$ were tested using a One-Way ANOVA with a Kruskal-Wallis test $(p<0.05)$. Spearman's correlation factor was also calculated.

\section{Results}

\section{Thermohaline structure}

During the sampling period, thermohaline structure was characterized both by spatial and vertical homogeneity, except on the $21^{\text {th }}$ February when temperature and salinity differed significantly in the water column. Early summer (December and January) presented colder waters (0.75 \pm $0.42{ }^{\circ} \mathrm{C}, \mathrm{n}=54$ ) than those observed during late summer $\left(1.61 \pm 0.15^{\circ} \mathrm{C}, \mathrm{n}=25\right)$. Although salinity decreased slightly during the sampling period, mean values were similar between early summer $(34.2 \pm 0.2, \mathrm{n}=51)$ and late summer $(34.1 \pm 0.2, \mathrm{n}=30)$ (Figures $2 \mathrm{a}$ and $2 \mathrm{~b})$.

\section{Chlorophyll a biomass and size structure}

Chlorophyll $a$ (Chla) biomass increased from early to late summer from $0.54 \pm 0.12 \mu \mathrm{g} \mathrm{L}-1(n=15)$ to $4.03 \pm 1.33 \mu \mathrm{g} \mathrm{L}^{-1}$ $(\mathrm{n}=15)$ and was positively correlated with temperature $(\mathrm{r}=$ $0.74, p<0.001$ ) (Figure 3a). Values lower than $1 \mu \mathrm{g} \mathrm{L}^{-1}$ were observed in $64 \%$ of the samples during early summer and only $17 \%$ in late summer. A significant spatial variability among each survey was not observed, except on $14^{\text {th }}$ December and $21^{\text {st }}$ February. BP showed biomass twice as high $\left(0,72 \mu \mathrm{g} \mathrm{L}^{-1}\right)$ than the other stations during the first survey, while on $21^{\text {st }}$ February the TP and AR presented biomass twice as superior $\left(2,64 \mu \mathrm{g} \mathrm{L}^{-1}\right)$ to the inner stations located in Mackellar and Martel inlet.

In early summer, picoplanktonic fraction $(<2 \mu \mathrm{m})$ represented on average $17 \pm 7 \%(\mathrm{n}=28)$ of $\mathrm{Chl} a$, whereas ultraplankton represented $33 \pm 10 \%(n=28)$ and microplankton accounted on average $51 \pm 11 \%(n=28)$. In late summer, microplankton contribution to Chla biomass increased and represented on average $88 \pm 10 \%(n=18)$ reaching over $93 \%$ at the end of the sampling period (Figure $3 \mathrm{~b}$ ). The vertical and spatial variability of size fractionated Chla was not significantly different $(p>0.05)$.

\section{Discussion}

Late summer values of temperature and salinity observed were similar to those reported in previous studies (Lange et al., 2007; Tenório et al., 2011), however early summer water temperatures were higher than those observed during summer 2009/2010 in the same Bay (Tenório et al., 2011).
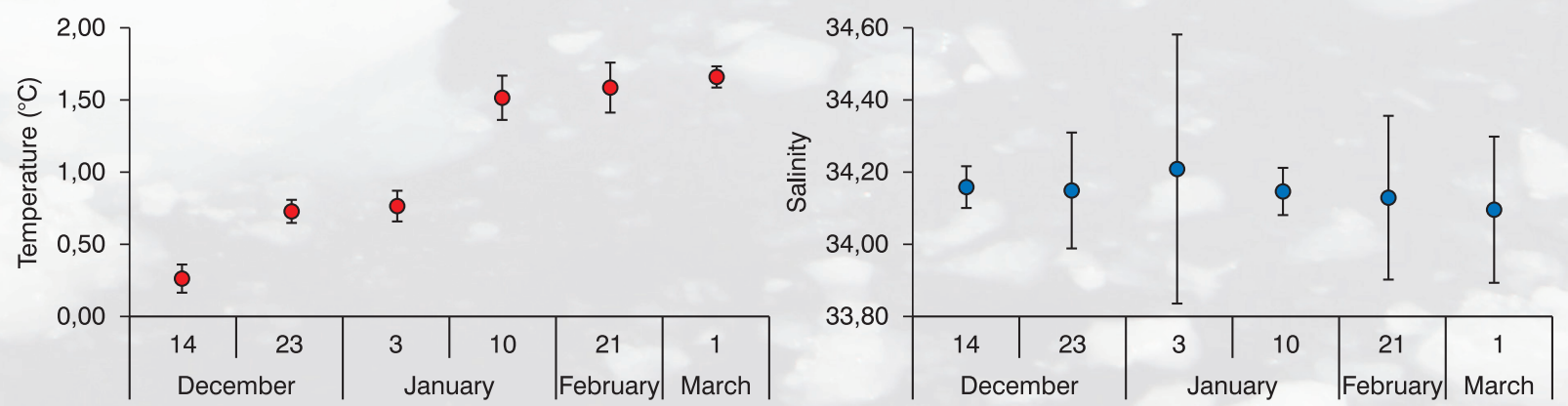

Figure 2. Temporal variation of water temperature (a) and salinity (b) in Admiralty Bay during December 2010 to March 2011. 

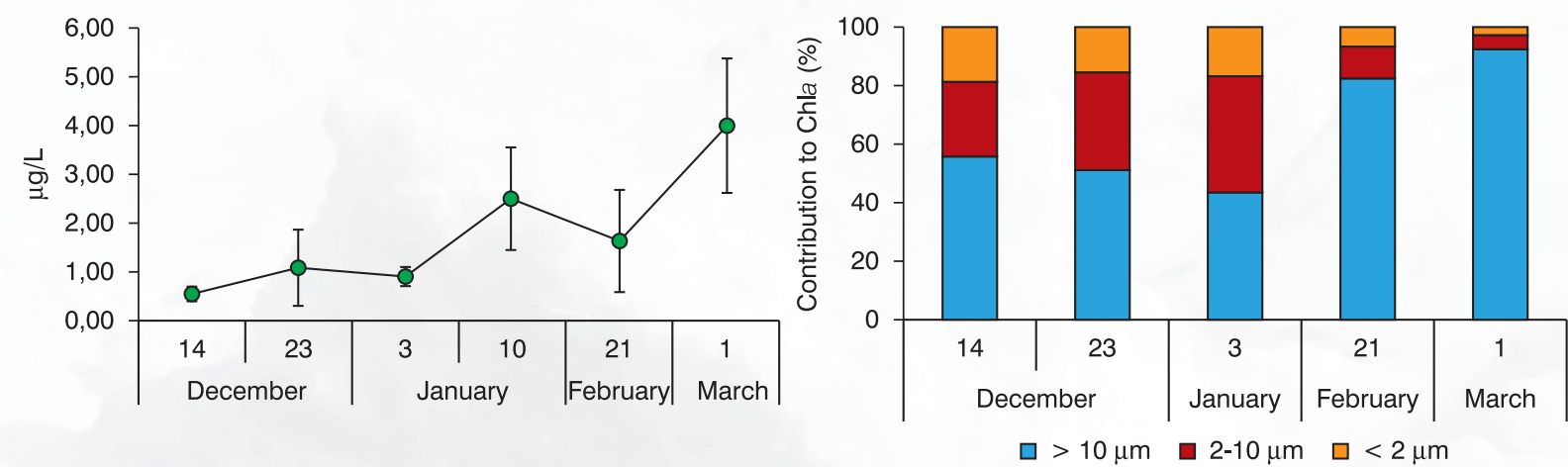

Figure 3. Temporal variation of Chlorophyll a: a) concentrations and b) contribution to size distribution in Admiralty Bay during December 2010 to March 2011.

Low Chla biomass $\left(\sim 2 \mu \mathrm{g} \mathrm{L}{ }^{-1}\right)$, as observed during early summer of 2010/2011, was commonly reported in previous studies in Admiralty Bay (Brandini, 1993; Lange et al., 2007, Tenório et al., 2011) as well as in adjacent areas (Brandini \& Kutner, 1986; Kang \& Lee, 1995) and in Antarctic oceanic waters (Platt et al., 2003). In late summer the increase of biomass was mainly conditioned by the rise of temperature that melts the ice providing the micronutrient iron to phytoplankton growth (Martin et al., 1991) and promoting water column stratification maintaining the phytoplankton in the euphotic zone (Lipski, 1987).

The size distribution of the primary producers plays an important role in the trophic organization of marine ecosystems and in the global flux of organic matter towards the water column (Jacques \& Panouse, 1991). During early summer biomass was co-dominated by ultra and microplankton representing $84 \%$ of Chla biomass, while in the late summer only microplanktonic fraction dominated completely Chla concentrations (88\%). Previous studies in the same area have reported the dominance of 2-20 $\mu \mathrm{m}$ size fraction on phytoplankton (Brandini, 1993; Kopczynska, 2008) or microplanktonic diatom dominance as observed on James Ross Island (Weddell Sea) (Souza, 2012). In this sense, a positive correlation with total chlorophyll biomass and microphytoplankton cells count $(r=0.77, p<0.05)$ was observed for Admiralty Bay by Barrera-Alba et al. (2012). Similarly, our results showed positive correlation between total Chl $a$ and microplanktonic fraction concentration ( $\mathrm{r}$ $=0.67, p<0.05$ ), pointing out that fraction was the main component of the phytoplankton community. However, this pattern was not observed in the previous study during the summer 2009/2010, when pico and ultraplankton dominated the Chla biomass (Tenório et al. 2011). This variability of the size structure and functional composition of phytoplankton are closely linked to physical, chemical and biologic factor gradients in the coastal waters (Rodríguez et al., 2002; Kang \& Lee, 1995).

The temperature sensitivity of planktonic organisms suggests that Southern Ocean plankton communities may be particularly sensitive to global warming (Wright et al., 2009). A change in the size spectrum of Southern Ocean phytoplankton would be expected to have serious consequences for krill and other herbivores that are adapted to a diet of nano- and microplankton, and would also affect the dynamics of the microbial loop and the transport of carbon to the deep ocean (Wright et al., 2009). These observations highlight the importance of a long-term monitoring study of $\mathrm{Chl} a$ size fraction data in this region.

\section{Conclusion}

The preliminary results of the present study showed a relatively spatial homogeneity in chlorophyll $a$ concentration. Temporal variation presented a significant variability between early and late summer, highlighting that a short-term temporal variation study is necessary to understand the environmental effects on phytoplankton organisms. Phytoplankton populations were co-dominated by ultra and microplankton, which represented more than $80 \%$ of chlorophyll $a$ concentrations. Chl $a$ biomass and size fractionated studies in Admiralty Bay proved to be a good tool for monitoring the global effect of changes on the region. 


\section{Acknowledgments}

This work integrates the National Institute of Science and Technology Antarctic Environmental Research (INCT-APA) that receive scientific and financial supports of the National Council for Research and Development (CNPq process: $n^{\circ}$ 574018/2008-5) and Research Support Foundation of the State of Rio de Janeiro (FAPERJ $n^{\circ}$ E-16/170.023/2008). The authors also acknowledge the support of the Brazilian Ministries of Science, Technology and Innovation (MCTI), of Environment (MMA) and Inter-Ministry Commission for Sea Resources (CIRM) and Marine Organic Chemical Laboratory of the Oceanographic Institute of São Paulo University (LabQOM-IOUSP). M. M. B. Tenório thanks FAPERJ/ CAPES for the post-doctoral fellowship under process $n^{\circ}$ E-26/102.015/2009.

\section{References}

Barrera-Alba, J.J.; Vanzan, M.; Tenório, M.M.B. \& Tenenbaum, D.R. (2012). Plankton structure of shallow coastal zone at Admiralty Bay, King George Island, West Antarctic Peninsula (WAP) During Early Summer/2010: pico, ultra and microplankton and chlorophyll biomass. Annual Activity Report/National Institute of Science and Technology Antarctic Environmental Research, 2012:101-105

Brandini, F.P. \& Kutner, M.B.B. (1986). Composition and distribution of summer phytoplankton in the Bransfield Strait, Antarctica. Anais da Academia Brasileira de Ciências, 58: 1-11

Brandini, F.P. (1993). Phytoplankton biomass in an Antarctic coastal environment during stable water conditions - implications for the iron limitation theory. Marine Ecology Progress Series, 93: 267-275.

Gin, K.Y.; Lin, X. \& Zhang, S. (2000). Dynamics and size structure of phytoplankton in the coastal waters of Singapore. Journal of Plankton Research, 22: 1465-1484

Jacques, G. \& Panouse, M. (1991). Biomass and composition of size fractionated phytoplankton in the Weddell-Scotia Confluence area. Polar Biology, 11: 315-328

Kang, S. \& Lee, S. (1995). Antarctic phytoplankton assemblages in the western Bransfield Strait region, February 1993: composition, biomass, and mesoscale distributions. Marine Ecology Progress Series, 129: 253-267.

Kopczynska, E.E. (2008). Phytoplankton variability in Admiralty Bay, King George Island, South Shetland Islands: six years of monitoring. Polish Polar Research, 29(2): 117-139.

Lange, P.K.; Tenenbaum, D.R.; Braga, E.S.B. \& Campos, L.S. (2007). Microphytoplankton assemblages in shallow waters at Admiralty Bay (King George Island, Antarctica) during the summer 2002-2003. Polar Biology, 30: 1483-1492.

Lipski, M. (1987). Variations of physical conditions, nutrients and chlorophyll a contents in Admiralty Bay (King George Island, South Shetland Islands). Polish Polar Research, 8: 307-332.

Marrari, M.; Kendra, L. D. \& Hu, C. (2008). Spatial and temporal variability of SeaWiFS chlorophyll a distributions west of the Antarctic Peninsula: Implications for krill production. Deep-Sea Research II, 55: 377-392.

Martin, J.H.; Gordon, R.M. \& Fitzwater, S.E. (1991). The Case for iron. Limnology and Oceanography, 36:1793-1802.

Mitchell, B.G. \& Holm-Hansen, O. (1991). Observations and modeling of the Antarctic phytoplankton crop in relation to mixing depth. Deep-Sea Research, 38: 911-1007.

Montes-Hugo, M.; Doney, S.C.; Ducklow, H.W.; Fraser, W.; Martinson, D.; Stammerjohn, S.E. \& Schofield, O. (2009). Recent Changes in Phytoplankton Communities Associated with Rapid Regional Climate Change Along the Western Antarctic Peninsula. Science, 323: 1470-1473.

Moura, R. B. (2009). Estudo taxonômico dos Holothuroidea (Echinodermata) das Ilhas Shetland do Sul e do Estreito de Bransfield, Antártica. Dissertação de Mestrado, Museu Nacional, Universidade Federal do Rio de Janeiro. 
